Рад примљен: 27. 2. 2019.

Рад прихваћен: 20. 4. 2019.

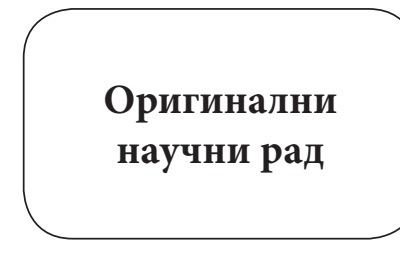

$$
\begin{array}{r}
\text { Sanela D. Šipragić Đokić1 } \\
\text { Belgrade Banking Academy - Faculty of Banking, } \\
\text { Insurance and Finance, Union University, Belgrade } \\
\text { Milena J. Tanasijević, } \\
\text { Belgrade Metropolitan University, Belgrade }
\end{array}
$$

\title{
Investigating the Effects of Portfolio Assessment in English Language Courses for Banking and Finance at University Level
}

\begin{abstract}
This paper investigates the role of portfolio assessment in LSP university courses. It also explores possibilities of integrating this type of (self-)assessment in the course development stage. Informed by needs analysis, portfolio assessment may serve as a proper tool for evaluation of language skills of LSP course participants, since it encourages task based learning as well as collaborative learning.

Portfolio is seen as a collection of students' papers, assignments and tasks which illustrates students' efforts, achievements and success in mastering Business English on core curriculum. It is a student-centred activity since it involves students in choosing and selecting materials, their selfreflection and self-assessment over time. It promotes the value of self-assessment, which has not been acknowledged in assessment practices in formal education yet. The second stage of portfolio assessment is provided by the lecturer.

This paper aims to provide reasons for introducing portfolio assessment as a bridge between students' self-assessment and formal assessment done by the lecturer. Moreover, it outlines the portfolio framework and its development in terms of its application in courses designed for students of banking. The paper further presents the results of the research into the effects of portfolio assessment among students conducted at the Belgrade Banking Academy.
\end{abstract} tion.

Key words: Business English, formal assessment, portfolio, self-assessment, university educa-

1 sanela.sipragic@bba.edu.rs

Copyright (c) 2019 by the authors, licensee Teacher Education Faculty University of Belgrade, SERBIA.

This is an open access article distributed under the terms of the Creative Commons Attribution License (CC BY 4.0) (https://creativecommons.org/licenses/by/4.0/), which permits unrestricted use, distribution, and reproduction in any medium, provided the original paper is accurately cited. 


\section{Introduction}

LSP course development at tertiary level is a complex process consisting of situational needs analysis, defining course objectives, syllabus design, lesson planning and course evaluation. In this paper the situational needs analysis and defining course objectives are briefly outlined. Greater emphasis is placed on the assessment processes.

Evaluation and assessment of language competence at LSP courses keep provoking interest of linguists, language teachers and lecturers, psychologists, pedagogists and all those intereseted and involved in the research of foreign language learning, teaching and assessment. The complexity of this conglomerate of issues brings about certain controversies, thus interpreting assessment at language for specific purposes courses as mere test-taking and a quantitative interpretation of their results as the main measure of students' language competence.

However, contemporary teaching practice places the student in the centre of the teaching process (Atkins and Brown, 2002). The world and the labour market have changed due to globalization, which consequently triggered changes in education and educational needs. The concept of education nowadays tends to be pragmatic. Active labour market participants are expected to possess skills, resources and specific knowledge which may help them to adjust to dynamic labour markets and differentiate from the competitors (Graddol, 2006).

Being specific in itself, teaching and learning of LSP at university can respond to challenges only if it constantly allows for the introduction of innovations and responds to the current needs. Reforms encouraged by the adoption of the Bologna Declaration required changes in traditional teaching and examination practices. Curricular reforms have insisted on a more transparent specification of learning outcomes, standards and assessment criteria. It may seem that the whole system brought about advantages in learning, knowledge acquisition and as- sessment. However, the process of assessment is still largely focused on formal and superficial measuring, not on a deep and qualitative evaluation.

Contemporary teaching and learning processes tend to be student-oriented, but in the centre of the assessment process and the procedure itself is the teacher. Testing and credits collecting is more common than assessing what students can really do and achieve in a foreign language for specific pursposes. Students learn to do tests and get marks, not to develop language competence and become aware what they can do with it. In order to make progress in development of their pragmatic competence, students have to be motivated (Sipragic Djokic et al., 2018:884). Assessment of students knowledge and achievements has to be motivating as well, and students' attention has to be directed towards activities. According to Hutchinson and Waters, ESP is an approach to language teaching in which all decisions as to content and method are based on the learner's reason for learning (Hutchinson and Waters, 1987:19). In order to help students take responsibilities in the process of assessment too, the teacher and the system should provide conditions which will support that idea.

\section{Curriculum Development of ESP Courses at Higher Education Institutions}

What makes LSP courses at university different from LSP courses in other contexts (for example, in-company courses or courses at language schools and institutes) is that generally, the instructor does not have enough autonomy to tailor the course to the needs of each particular learner. Still, the curriculum development process follows the stages of each curriculum cycle, namely:

- Needs analysis - in this case primarily situational analysis

- Defining course objectives

- Defining assessment methods and tools

- Syllabus design 
- Lesson planning

- Course evaluation

\section{Situational Analysis for English Language Courses at Belgrade Banking Academy}

The situational analysis conducted for the purpose of this research paper revealed several significant aspects of curriculum development which needed to be taken into account at the planning stage:

- the overall learning objective(s) of a study programme - at the Belgrade Banking Academy - Faculty of Banking, Insurance and Finance, the bachelor study programme is called Economics and Finance. There are two modules: Banking, Insurance and Finance, as well as Finance and Accounting. The overall learning objective of the study programme is to develop students' critical thinking abilities in order to evaluate the application of modern-day complex methods, techniques and models when making financial business decisions (http://bba.edu.rs).

- English was a mandatory course for all six semesters (three academic years) at the time the research was carried out

- the number of ECTS per course - the value of ECTS points reflects the overall workload of a student in a working week, (Đorović and Janković, 2018:121), as well as the number of teaching hours (lectures and exercises). Each English course carried 4 ECTS points which roughly equals to 5 to 6 hours workload for students per week (a total of 75 to 80 hours including lectures and tutorials). There were four classes per week (3 hours of language instruction in the form of both lectures and tutorials) which allowed for approximately 30 to 40 hours for self-study (for work on course assignments, as well as for studying)
- the expected language level at the completion of bachelor studies is B2 in order to allow students to pursue master academic studies or participate in exchange programmes in institutions under the umbrella of the Bologna process (Vučo, 2018:76)

- number of students per group - primarily large groups (40 + learners, within mixedlevel groups)

- availability of teaching material - course book and study material available to students

- the need for continuous assessment during course implementation - as part of the requirements of Bologna declaration the overall course completion mark reflects evaluation of learners' work during the course implementation stage, as well as the final exam result

- teaching approach - primarily task-based and content-based teaching

- learner needs - one of the overall learner needs in LSP courses at tertiary level would be to develop learner autonomy (students take responsibility for their learning)

- the need for collaborative learning

\subsection{Defining Course Objectives}

The process of formulating course aims and objectives is widely discussed in literature. Course aims are viewed as general principles guiding a curriculum and objectives are viewed as more specific and concrete description of purposes (Richards, 2001:120). In our case, the aims of the English courses are as follows:

- In the first year of studies the course is designed to facilitate development of the four language skills: listening, speaking, reading and writing. Students are encouraged to acquire technical terms and business vocabulary, which enables them to use the 
language of their future jobs in the field of banking and finance. Along with the textbook, students work with authentic material which is tailor-made for the purpose of their studies. Through different types of activities students are exposed to situations which simulate their future business needs. They are encouraged to engage in a democratic dialogue developing tolerance for different opinions and attitudes.

- During the second year of studies the English Language Course is designed to enable students to further develop the four language skills: listening, speaking, reading and writing. Students are encouraged to communicate and work collaboratively. They work on developing specific soft skills necessary in business presentations, negotiations and conducting and participating in business meetings. Through different types of activities students are exposed to situations which simulate their future business needs.

- In the third year of their studies students attend the English Language Course the main aim of which is to enable them to acquire the language in the specific field of banking, insurance and finance through activities based on authentic materials. Students develop business communication skills and are able to use academic literature in the English language. They deal with a variety of topics, ranging from money, banking, bank products, financial markets, accounting, economic audit, stock exchange, etc.

The learning objectives are the following:

- Upon the completion of the first year of studies students are able to take simple notes and messages, understand simple presentations on familiar business topics, receive incoming phone calls on predict- able subjects, as well as understand simple instructions. They can also understand and translate short texts on familiar matters with predictable contents. They can write simple formal e-mails, memos, timetables and simple agendas for the meeting, as well as their own CVs.

- After the course completion at the second year of studies, students are able to take most messages that are likely to be exchanged during the day. They can interpret graphs and charts containing a limited number of items. They can greet visitors and engage in simple introductions and simple small talk. Also they can use words and expressions regarding career, dealing with customers, types of organisations, marketing basics and trends.

- Students can give presentations on a variety of familiar topics and respond spontaneously to questions. They can take part in business interviews. They can understand longer texts on unfamiliar matters if given enough time. They can write simple business reports on predictable contents and familiar topics. They can take part in prepared negotiations on familiar issues. They can handle semi-complex issues on financial matters to the extent of the necessary, purpose-specific background knowledge. They can understand most correspondence and reports of substantial length and formality. They can write longer memos and e-mails, orders and requests as well as complaints on unpredictable and unfamiliar topics.

- After the third year of studies, students can understand complex conversations on business topics. They can speak about and advise on financial matters. They can express their ideas in a logical sequence, taking part in negotiations on unpredictable 
business matters stating accurately the arguments supporting and/or opposing the points of view. They can understand long and complex texts expressed in complex language on unpredictable matters in the field of business and finance

\section{Defining Assessment Methods and Tools}

In order to satisfy the requirements of the situational needs analysis, the curriculum for English at the Belgrade Banking Academy needed to have a strong assessment frame throughout the course implementation, as well as the final exam.

This research was carried out during the spring semester when students took English 2 (a Business English course at A2 level), English 4 (a Business English Course at B1 level), as well as English 6 (a Business English Course at B2 level). The assessment frame for these courses was the following:

- Listening Comprehension Test taken in the $5^{\text {th }}$ week carrying 35 points maximum

- Grammar and Vocabulary Test taken in the $10^{\text {th }}$ week carrying 35 points maximum

- Portfolio submitted in the $12^{\text {th }}$ week carrying 30 points maximum

\section{The Role of Portfolio Assessment - Theoretical Framework}

European language portfolio is a personal document which enables language learners to improve their knowledge and enrich their intercultural experiences. It can also be used to present the current level of knowledge of foreign languages in accordance with the levels of knowledge defined by the Council of Europe (CEFR, 2001; ELP, 2006).

Introduction of the language portfolio in the assessment process enables teachers to measure student achievements and capabilities, giving them feedback in the form of a detailed comment which may help students obtain not only a comparable, but a more comprehensive measure of language competence.

According to CEFR (CEFR, 2001:43-49), language portfolio is a complex instrument for the (self-)assessment of language competence, in accordance with the reference level introduced by the Council of Europe and, at the same time, it is a document which provides information on a language learner's communication competences in a foreign language.

For the purpose of this paper portfolio can be understood as an alternative, innovative way of assessment procedure. It is a process of developing different pieces of writing, self-reflection, correcting and collecting documents. It may also be understood as a step forward from producing a correct and accurate language towards selecting, organising and presenting ideas in order to achieve an effective communication. The test is a final product which cannot be changed and improved. It can be re-taken in the next exam period, but never the same one. On the other hand, documents produced for the portfolio can be reviewed, revisited, changed and improved several times before both a student and a teacher are satisfied with the final version. It encourages students' self-assessment as well, making it an integral part of the pedagogic process (Kostopoulou, 2008:127-128) that claims to view learners and their needs from a holistic perspective because it satisfies their educational, emotional, psychological and social needs and promotes their selfactualisation.

Since students are treated as important partners in the learning and assessment process, their motivation is enhanced, along with their self-esteem and the sense of responsibility. According to Little (Little, 2009: 224-226), the three most important points of learner autonomy are empowerment, reflection and an appropriate target language use. Language portfolio accommodates all these three principles, since students can reflect on what they did in 
a foreign language, they become responsible to do the tasks in a due time, they have control over the content of their documents, and, above all, their linguistic competence is promoted because they think and write in the target language.

\section{The Shift from Test-Based Assessment towards Performance-Based Assessment}

Until the year 2010 traditional assessment at Belgrade Banking Academy used to be done through written tests containing reading comprehension, grammar and vocabulary and oral exams which were conducted mainly in the form of a dialogue or discussion between a student and a teacher based on topics offered in the coursebook and determined by the syllabus. The written exam was eliminatory. Both written and oral exams were criterion-referenced and students were given grades on the scale from 6 to 10 for the pass. The tests (written exams) usually lasted 1,5 hours and the oral part followed 3-5 days after the written exam. (Šipragić Đokić, S., 2011:308)

The new system of assessment which involved language portfolio development was first applied in 2010. The portfolio assessment consists of three parts: the obligatory part marked with the red label, the semi-obligatory part marked with the yellow label and the free task marked with the green label.

At the beginning of the semester students are explained the concept of the language portfolio and given instructions in terms of document collection, selection and development. Students were asked to prepare folders for the collection of their papers. It is crucially important to give students concrete, clear and specific instructions on what they should do and what they are expected to do for each task (Oscarsson, 1997; Weigle, 2002).

The obligatory part marked with the red label consists of 4 tests students have taken during the academic year - reading comprehension test, two grammar and vocabulary tests and listening comprehension test.
The semi-obligatory part marked with the yellow label is the largest part of the portfolio and it encourages collection, selection and reflection of papers (Hamp-Lyons and Condon, 2000), which are the three crucial elements of any portfolio. Students are given tasks designed by the teacher and a pre-defined time framework in which they are supposed to finish the tasks. The teacher facilitates the process of the portfolio development and takes an active part in monitoring student achievement during the semester. The tasks are designed in accordance with the syllabus and enable students to learn and show progress in all language domains and skills such as listening, reading, speaking and writing, developing their cognitive, meta-cognitive and pragmatic competences. Students are given immediate feedback by the teacher according to which they can make changes and improve their documents. The tasks themselves are presented in the appendix of this paper.

The free tasks marked with the green label required students to produce and submit any other document of their own choice. Students are asked to explain their choices as a brief introduction to the task.

\section{Research}

\section{The Aim of the Research}

The primary aim of this research was to analyze the effects of this new method of assessment which, apart from incorporating skills assessment (reading comprehension and listening comprehension) as well as grammar and vocabulary tests, involved developing a language portfolio. We wanted to check the effects of the final grade students achieved, depending on whether its formation involved compulsory submission of the portfolio or the students passed the exam with successful results without this requirement. The defined research task was carried out by setting and testing the following hypotheses: 
Ho: Preparation and submission of a portfolio as a compulsory part of an exam does not affect the overall success that students achieve

$\mathrm{H}_{1}$ : Development and submission of a portfolio as a compulsory part of an exam affects the overall success that students achieve

\section{Methodology}

In order to check the hypotheses, we analyzed the work of two groups of students, an experimental and a control group. The experimental group consisted of a total of 87 students who completed the portfolio assignment prior to the exam (29 students per year). The control group consisted of 87 students who did not submit the portfolio. The results were analysed with the statistical t-test using SPSS software.

\section{Empirical Research}

The first part of the research shows the basic indicators of the descriptive statistics. The values of mean, standard deviation and standard error of the mean for the data on exam results achieved by students who submitted portfolio and those who did not submit portfolio are shown in Table 1.
The next output (Table 2) represents the results of the conducted t-test.

It can be seen from Table 2 that the value of $\mathrm{t}$ statistics is 7.122. This t-value is significant as the $\mathrm{p}$ value is 0.000 which is less than 0.05 . Thus, the null hypothesis of equality of average score on exam with or without the submission of the portfolio is rejected, and therefore, it may be concluded that the average score on exam with and without submitting portfolio is not the same. Further, by looking at the values of the students' score with or without portfolio in Table 1 , it can be noted that the average score has increased after including the portfolio. Since the null hypothesis was rejected, it may thus be concluded that the increase in the score on the exam significantly increased due to having portfolio as a part of the exam.

\section{Advantages and Disadvantages of Portfolio Assessment}

Language portfolio is a purposeful collection of students papers which encourages students to become more active and more motivated. It shows students' gradual progress in mastering and developing language competence and raises students' awareness of their own success and improvement.

\begin{tabular}{ccc|c|c|c} 
& & Mean & $\mathrm{N}$ & Std. Deviation & Std. Error Mean \\
\hline Pair 1 & Exam result with portfolio & 25.7816 & 87 & 3.34256 & .35836 \\
\cline { 2 - 6 } & $\begin{array}{c}\text { Exam result without port- } \\
\text { folio }\end{array}$ & 20.4943 & 87 & 5.25816 & .56373 \\
\hline
\end{tabular}

Table 1: Paired sample statistics

\begin{tabular}{|c|c|c|c|c|c|c|c|c|c|}
\hline & & \multirow[b]{2}{*}{ Mean } & \multirow{2}{*}{$\begin{array}{c}\text { Std. } \\
\text { Deviation }\end{array}$} & \multirow{2}{*}{$\begin{array}{l}\text { Std. } \\
\text { Error } \\
\text { Mean }\end{array}$} & \multicolumn{2}{|c|}{$\begin{array}{l}\text { 95\% Confidence Interval } \\
\text { of the Difference }\end{array}$} & \multirow[b]{2}{*}{$\mathrm{T}$} & \multirow[b]{2}{*}{$\mathrm{df}$} & \multirow{2}{*}{$\begin{array}{c}\text { Sig. } \\
\text { (2-tailed) }\end{array}$} \\
\hline & & & & & Lower & Upper & & & \\
\hline Pair 1 & $\begin{array}{c}\text { Exam result with } \\
\text { portfolio - Exam re- } \\
\text { sult without portfolio }\end{array}$ & 5.28736 & 6.92469 & .74240 & 3.81150 & 6.76321 & 7.122 & 86 & .000 \\
\hline
\end{tabular}

Table 2: Paired t-test for the data on exam results 
Assessment based on developing a portfolio is not based on the mere quality of the document as a final product. Its main value is in the process of evaluation of the individual effort and achievement. As such, it is particularly suitable for mixedability classes. Since students have a choice, they can apply different learning styles. Being a personalised document, it boosts motivation, enhancing achievement and progress in the long run. Students' results are not only expressed quantitatively in the form of the final grade, but build up and give a cumulative image which is explained in teacher's feedback. Expressed not only in quantitative, but also qualitative terms, such feedback gives students more information on their real achievement.

Portfolio assessment has some disadvantages, a few of which will be mentioned here. First of all, it may be time-consuming for students because collecting and selecting documents takes time. Also, it requires constant engagement of the teacher in terms of giving feedback mainly in writing so that students can remedy and improve their documents. Secondly, it should also be taken into consideration that students often resist change no matter what benefits it may bring or they might not work on the portfolio assessment individually. Thirdly, some students consider collection and development of documents as a copy-paste activity or they do not stick to the time framework defined at the beginning of the semester, which should be recognised by the teacher on time.

In spite of the disadvantages, the benefits of portfolio assessment are numerous. Apart from enhancing motivation, it enables students to develop their cognitive, meta-cognitive and pragmatic abilities. Development of the portfolio is not only resultoriented and criterion-referenced (Douglas, 2000) but process-oriented. It encourages learner autonomy and puts students in the centre of the teaching and learning process. It entails the self-assessment components, shifting the assessment process from the control and authority of the teacher to a more learner-centred approach requiring active involvement of students in all pedagogic procedures and enabling them to take a full responsibility for their progress.

Further engagement can be directed towards creating an e-portfolio, which is not a new concept since it was introduced as early as 1990s but still not applied in our institution, as well as developing precise assessment rubrics in order to make this assessment model even more transparent.

\section{Conclusion}

Assessment in LSP courses at university level is a complex process and has to be determined during the course preparation stage. LSP tertiary courses at BBA allow students 35-40 hours of self-study in order to prepare for tests and exams. This paper investigated the impact of the portfolio assessment conducted during the self-study period. It presented a model of portfolio assessment describing its mandatory and optional elements. It analysed the impact of portfolio preparation on the overall success of students at the final exam and their achievement in English. The paper also pointed out some of the disadvantages of this type of assessment. However, the disadvantages can be viewed as challenges which need to be overcome. Further research would involve the steps of developing an e-portfolio, as well as work on preparing precise assessment rubrics for the tasks.

\section{References:}

- Atkins, M., \& Brown, G. (2002). Effective teaching in higher education. Routledge.Council of Europe (2001).

- Council of Europe (2001). Common European Framework of Reference for Languages: Learning, Teaching, Assessment. Cambridge: CUP 
- Council of Europe (2006).: Key reference documents: Strasbourg: Council of Europe (DGIV/EDU/LANG, 2006,4) European Language Portfolio (ELP)

- Douglas, D. (2000). Assessing Languages for Specific Purposes, Cambridge: CUP

- Đorović, D., Janković, N. (2018). Bodovna vrednost stranog jezika struke na Beogradskom univerzitetu. In A. Vujović, S. Šipragić Đokić, M. Paprić (Ur.), Language for Specific Purposes and Professional Identity (pp.119-137), Foreign Language and Literature Association of Serbia and Teacher Education Faculty, University of Belgrade, Belgrade

- Graddol, D. (2006). English next (Vol. 62). London: British Council.

- Hamp-Lyons, L., \& Condon, W. (2000). Assessing the portfolio: Principles for practice, theory and research. Cresskill: Hampton Press

- Hutchinson, T., \& Waters, A. (1987). English for specific purposes. Cambridge University Press.

- Kostopoulou, S. (2008). Learner Self-Assessment: Innovation and Change in the Culture of Assessment. Journal of Postgraduate Research, 119-135.

- Little, D. (2009). Language learner autonomy and the European language portfolio: Two L2 English examples. Language teaching, 42(2), 222-233.

- Oscarsson, M. (1997). Self-Assessment of Foreign and Second Language Proficiency. In The Encyclopedia of Language and Education, Vol. 7 Kluwer Academic Publishers, pp. 175-187

- Richards, J.C. (2001). Curriculum Development in Language Teaching, Cambridge, CUP

- Šipragić Đokić, S. (2011). Assessing Languages for Business Purposes - from Tests to Performance-Based Assessment. In A.Ignjačević, D.Đorović, N.Janković, M.Belanov (Ur.), Languages for Specific Purposes: Challenges and Prospects, Foreign Language and Literature Association of Serbia, Belgrade, pp. 305-313

- Šipragić Đokić S., Čajka, Z., Tanasijević, M., (2018): O nekim problemima vrednovanja znanja engleskog jezika ekonomske struke u visokom obrazovanju. In: A. Vujović, S. Šipragić Đokić, M. Paprić (Ur.), Strani jezik struke i profesionalni identitet, Tematski zbornik, Foreign Language and Literature Association of Serbia, Teacher Education Facultz, University of Belgrade, pp. 881-895

- Vučo, J. (2018). Internacionalizacija univerziteta i jezičke potrebe In A. Vujović, S. Šipragić Đokić, M. Paprić (Ur.), Language for Specific Purposes and Professional Identity (pp.69-83), Foreign Language and Literature Association of Serbia and Teacher Education Faculty, University of Belgrade, Belgrade

- Weigle, S.C. (2002). Assessing Writing. Cambridge: CUP

- http://bba.edu.rs 


\section{Appendix I}

\section{Tasks for Portfolio - Yellow Label - First year}

1. Choose 5 new words from each unit for your vocabulary journal. Copy the sentence in which your target words appear. For each new word you will need several lines. In the first line write the target word. On the second line copy the sentence in which your target word appears. On the next line, write a definition. State if the target word is a noun, a verb, an adjective or an adverb. If it is a noun, write both singular and plural forms, if possible. Then write a sentence of your own with the target word.

2. A-Z of you

3. Choose one activity from each unit from the course book, make copies of these activities and describe what you have learnt from these activities, respectively.

4. Find a photo of an unknown person and invent his/her biography.

5. Make a list of the business news you have listened to on the Internet and briefly report on each.

\section{Appendix II}

\section{Tasks for Portfolio - Yellow Label - Second year}

1. Choose 5 new words from each unit for your vocabulary journal from each unit. Copy the sentence in which your target words appear. For each new word you will need several lines. In the first line write the target word. On the second line copy the sentence in which your target word appears. On the next line, write a definition. State if the target word is a noun, a verb, an adjective or an adverb. If it is a noun, write both singular and plural forms, if possible. Then write a sentence of your own with the target word.

2. A-Z of your studies

3. Choose one activity from each unit from the course book, make copies of these activities and describe what you have learnt from these activities, respectively.

4. Find templates for the following documents: CV (European type), CV (American type), memo and a business card.

5. Make a list of the business news you have listened to on the Internet and briefly report on each.

\section{Appendix III}

\section{Tasks for Portfolio - Yellow Label - Third year}

1. Choose 5 of the new words from each unit for your vocabulary journal from each unit. Copy the sentence in which your target words appear. For each new word you will need several lines. In the first line write the target word. On the second line copy the sentence in which your target word appears. On the next line, write a definition. State if the target word is a noun, a verb, an adjective or an adverb. If 
it is a noun, write both singular and plural forms, if possible. Then write a sentence of your own with the target word.

2. A-Z of banking

3. Choose one activity from each unit in the course book, make copies of these activities and describe what you have learnt from these activities.

4. Find 3 original banking documents (a bank statement, an order, a note, etc.) and translate them into English. The documents can be downloaded from the Internet or obtained from the high street banks.

5. Imagine that you are a famous journalist who writes for the Finance Daily and you have to make an interview with a famous businessman/businesswoman/a banker/a portfolio manager/a professor of Economics/a commissionaire for securities, etc. Write the whole interview including your questions and his/her answers. 
Санела Д. Шипрагић Ђокић

Универзитет Унион, Београдска банкарска академија, Факултет за банкарство, осигурање и финансије, Београд

\title{
Милена Ј. Танасијевић
}

\author{
Универзитет Метрополитан, Београд
}

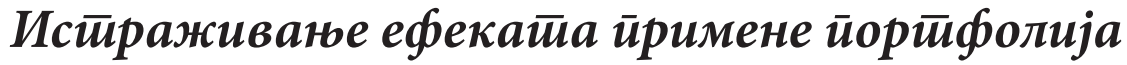 у оцењивању на курсевима Енїлескої језика за банкарсйво и финансије на универзитиетиском нивоу}

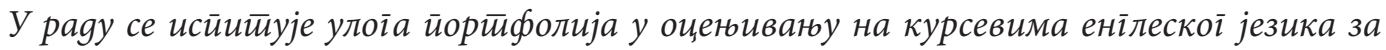

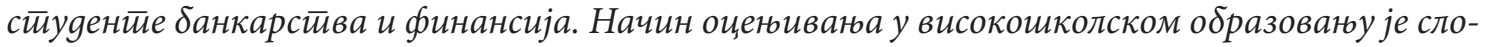

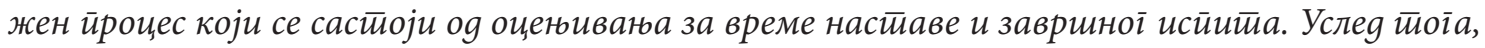
начин оцениваюа тиреба gа се осмисли уз иррииррему курикулума. Зајеgнички евройски оквир

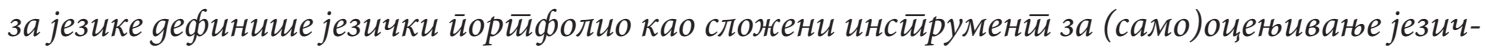
ких комиетеиениија у склаgу са нивоом знаға језика йо йрейорукама Саветиа Евройе. Језички

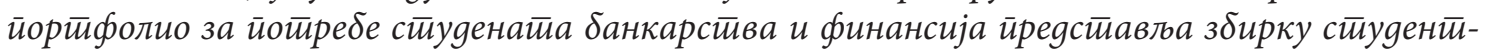

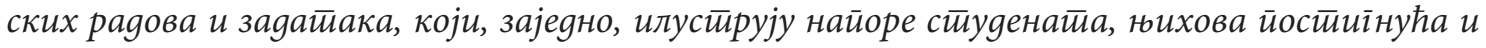
усиех у савлаgавану Пословноі енілескоі језика као обавезноі йреgметиа на основним сииу-

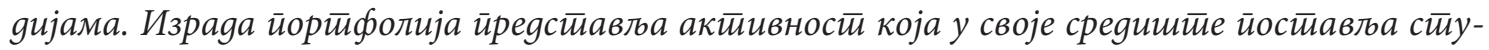

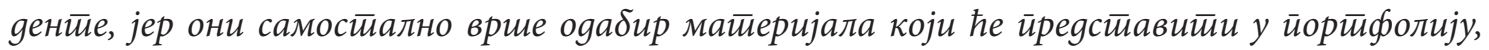

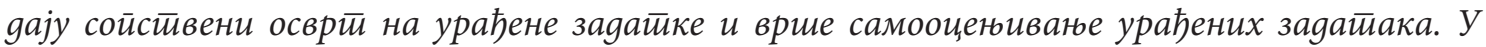

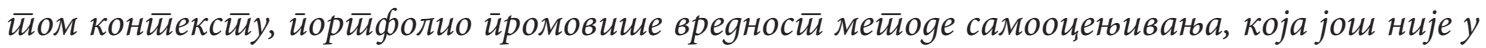

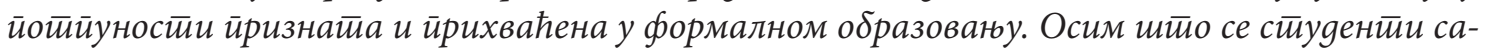

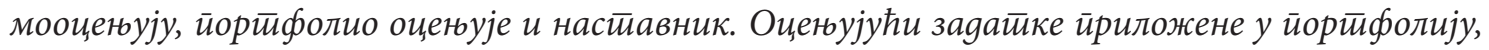

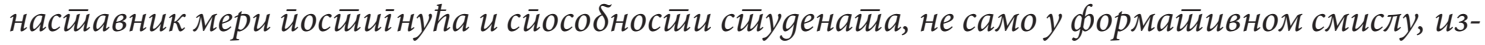

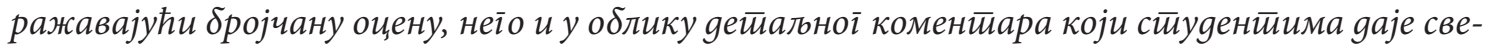

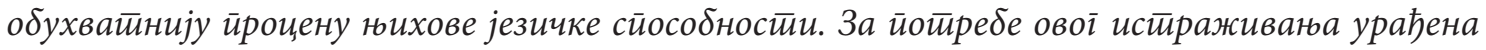
је сийуациона анализа йотиреба након које смо gебинисали иилеве и исходе курсева Посло-

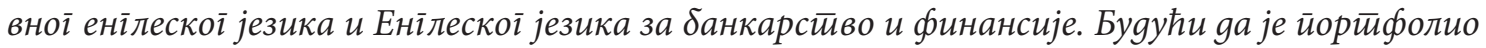

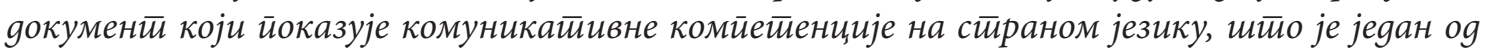
циљева курса, сирровели смо истираживаюе које је за ииль имало анализу учинка овоі йос-

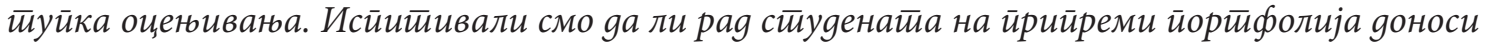

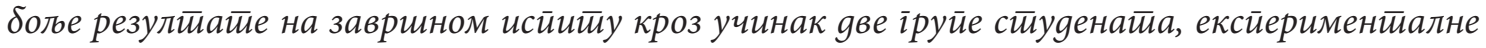

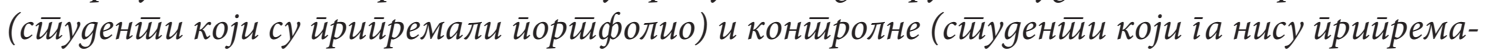

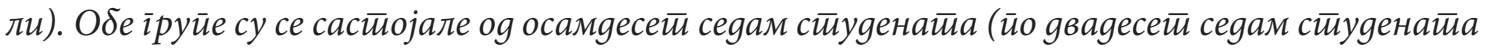

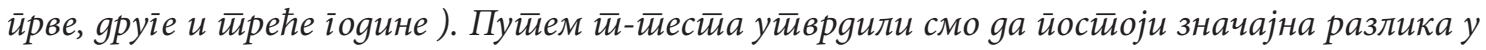




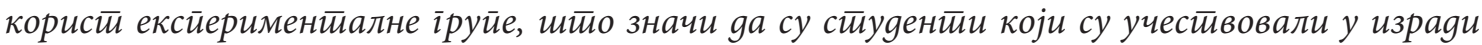

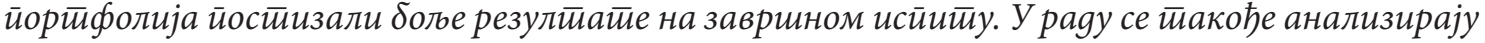

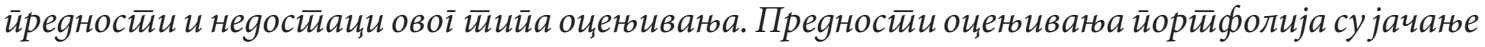

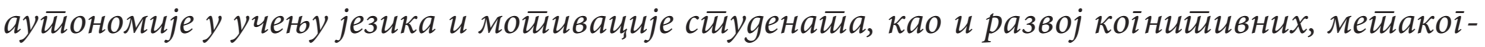

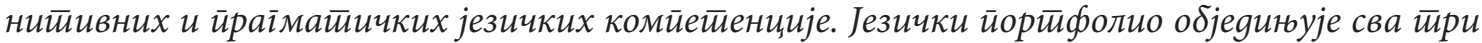

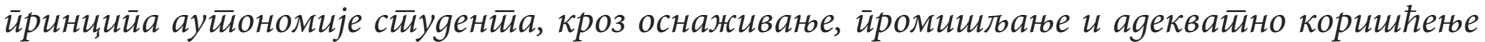

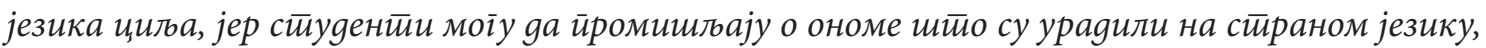

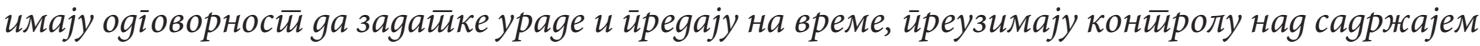

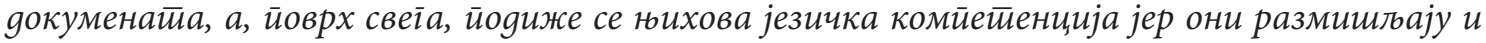
йишу на језику иильа. Оиениване йорйболија изискује време и иосвећености, како сииудена-

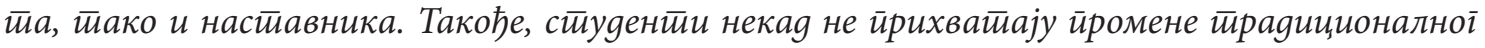

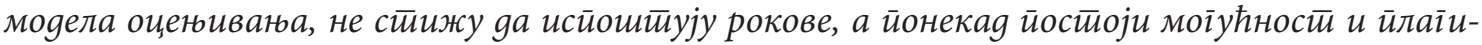

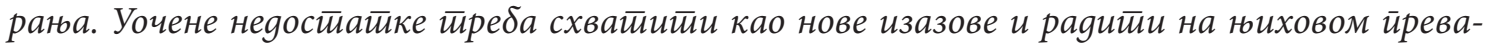

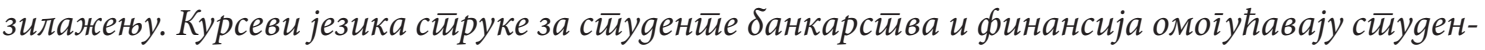

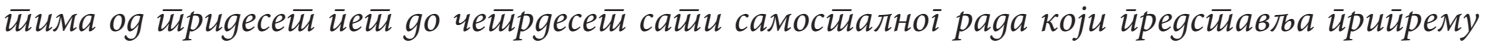

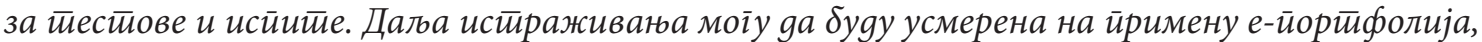
као и на израяи иррецизних рубрика за оцениване, ийо би овај вия оценивана учинило још

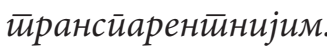

Кльучне речи: йословни енілески језик, (само)очениване, йорйбболио, универзийейско образоване. 